\title{
Effects of 1-MCP and calcium chloride treatments on quality maintenance of full-ripe cherry tomatoes
}

\author{
Yan Wunna Thwin ${ }^{1,2}$, Min Sun Chang ${ }^{2}$, Yoonpyo Hong ${ }^{2}$, Sooyeon Lim² \\ ${ }^{1}$ Postharvest Research Institute, Department of Agricultural Research, Yezin 15013, Myanma \\ ${ }^{2}$ National Institute of Horticulture and Herbal Sciences, RDA, Wanju 55365, Korea
}

\begin{abstract}
This study aims to elucidate the effects of separate or combined 1-methylcyclopropene (1-MCP) and calcium chloride $\left(\mathrm{CaCl}_{2}\right)$ treatment on the post-harvest quality of full-ripe chenry tomatoes (TY high $\mathrm{Q}$ cultivar). Full-ripe chenry tomatoes were exposed to $500 \mathrm{ppb} 1-\mathrm{MCP}(14 \mathrm{~h}), 2 \% \mathrm{CaCl}_{2}(2 \mathrm{~min})$, or a combination of both. After treatment, the fruit were evaluated based on the changes in their physicochemical factors, antioxidant activities, lycopene contents, and insoluble pectin contents during storage at $10^{\circ} \mathrm{C}$ over 17 days. All chemical treatments prevented weight loss and reductions in the insoluble pectin contents over the 17 days period, and also over an additional distribution period of 4 days, when compared to the control fruit. Interestingly, the full-ripe cherry tomatoes treated 1-MCP with $\mathrm{CaCl}_{2}$ exhibited a delay in discoloration until 13 days after treatment compared to the control. In addition, the synergetic effect of 1-MCP and $\mathbf{C a C l}_{2}$ was revealed by following their lycopene levels and antioxidant activities during storage. Furthermore, the insoluble pectin contents of the cheny tomatoes subjected to the combined treatment were higher than those recorded for the separate treatments. These results suggest that treatment with a combination of 1-MCP and $\mathrm{CaCl}_{2}$ can be useful as a post-harvest technique to improve both the post-harvest quality and the beneficial properties of cherry tomatoes even when the fruit is approaching the full-ripe stage.
\end{abstract}

Key words : chenry tomato, full-ripe stage, 1-MCP, $\mathrm{CaCl}_{2}$, antioxidant ability

\section{Introduction}

The cherry tomato (Lycopersicon esculentum var. TY high Q) is an important crop, cultivated in the tropical and sub-tropical regions in the world because of its nutritional and economic value. Several bioactive compounds present in cherry tomatoes, including lycopene, phenolics, vitamin C, and small amounts of vitamin $\mathrm{E}$, have been offered as part of a health-promoting diet (Giudice et al., 2015). Although the characteristic of tomatoes, such as a short life span, high yields, and year-round productivity, render them profitable to farmers (Noonari et al., 2015), they are prone to high post-harvest losses due to perishability, and so under unfavorable conditions, the ripe tomatoes exhibit a poor flavor and shortened storage life (Malundo et al., 1995). As a result, several post-harvest technologies, such as refrigeration storage (Batu and Thompson, 1998), modified atmosphere packaging (Park et al., 2012), heat treatment (Lurie and Klein, 1992), 1-methylcyclopropene application (1-MCP) (Cliff et al., 2009), calcium chloride $\left(\mathrm{CaCl}_{2}\right)$ application (Senevirathna and Daundasekera, 2010), and UV-C irradiation (Mansourbahmani et al., 2017), have been developed to maintain the quality and shelf-life of tomatoes (Arah et al., 2016). However, the influences of intrinsic and extrinsic factors on tomato crops have yet to be examined in detail in this context (Luengwilai et al., 2012).

*Corresponding author. E-mail : sylim84@korea.kr, Phone : +82-63-238-6557, Fax : +82-63-238-6505

Received 25 February 2020; Revised 11 May 2020; Accepted 12 May 2020.

Copyright (c) The Korean Society of Food Preservation.

This is an Open Access article distributed under the terms of the Creative Commons Attribution Non-Commercial License (http://creativecommons.org/licenses/by-nc/4.0) which permits unrestricted non-commercial use, distribution, and reproduction in any medium, provided the original work is properly cited. 
Fresh market cherry tomatoes are known to be of their best quality when the fruit is harvested at nearly the full-ripening stage (Roberts et al., 2002), however fully-ripe fruits rapidly soften, thereby leading to a shortened shelf-life (Krumbein, 2004; Kader et al., 1978). The ripening process of tomatoes is associated with exogenous or endogenous sources of ethylene (Blankenship and Dole, 2002), and so controlling ethylene biosynthesis, the freshness of harvested cherry tomatoes can be extended. More specifically, ethylene biosynthesis can be regulated through the application of 1-MCP, which binds to ethylene receptors and inhibits the various ripening-related biochemical changes, such as those attributed to cell wall degradation enzymes (Wills and $\mathrm{Ku}, 2002$; Mostofi et al., 2003), lycopene accumulation (Njoroge et al., 1998; Opiyo and Ying, 2005), reducing the level of expansin mRNA (Hoeberichts et al., 2002), and phytochemical oxidation (Watkins, 2006). Thus 1-MCP has the ability to extend the storage life of cherry tomatoes. Moreover, the efficacy of application is higher at the pre-climacteric stage rather than in the climacteric stage. Consequently, the function of 1-MCP, which interrupts the progress of ripening, is as a temporary treatment during the advanced stages of ripening (Mir et al., 2004). Although it is widely used in horticultural industries due to its odorless and nontoxic nature in addition to a high efficacy at low dosages (Cliff et al., 2009; Blankenship and Dole, 2003), the required concentration and length of exposure must be varied depending on the type of species and variety to control the storage quality, shelf-life, and injury.

Recently, $\mathrm{CaCl}_{2}$ treatment has also been used to preserve horticultural crops and delay their softening, ripening, and deterioration, as well as for its role in sanitizing the food (Genanew, 2013). Calcium serves as a strong chelator in the linkage of cell wall constructions (Shiri et al., 2014), and as an inhibitor of cell wall degradation enzymes (Awang et al., 2013; Mansourbahmani et al., 2017). Moreover, calcium is an important mineral that influences the softness of fruit, its quality, post-harvest decay, and physiological disorders (Lurie, 2009).

To date, studies into the potency of exogenous chemicals on fruit have focused on the dosage procedures, such as concentration, treatment time, and fruit maturity, due to the differences in fruit response after treatment. In addition, the efficacy of separately employing $\mathrm{CaC}_{2}$ and $1-\mathrm{MCP}$ on the storage-life and post-harvest quality of tomatoes has been proven by a number of studies (Watkins, 2006; Wills and $\mathrm{Ku}, 2002$; Njoroje et al., 1998). However, the comparative or complementary effects of 1-MCP and $\mathrm{CaCl}_{2}$ on the physiological, biochemical, and cell wall metabolism responses of fully-ripe cherry tomatoes have received little attention. The objective of this study is therefore to evaluate the individual and synergistic effects of $1-\mathrm{MCP}$ and $\mathrm{CaCl}_{2}$ on these factors in fully-ripe cherry tomatoes.

\section{Materials and methods}

\section{Plant materials and chemical treatments}

"TY high Q" cherry tomato, a plant material obtained from Jeongeup APC (agricultural product processing center) was used and screened based on uniformity and freshness. The cherry tomato was sanitized using $100 \mathrm{ppm}$ of sodium hypochlorite for $2 \mathrm{~min}$ and then, directly washed using tap water. In order to optimize the concentration of 1-MCP and $\mathrm{CaCl}_{2}$ in cherry tomato, three doses $(10,100,500 \mathrm{ppb})$ for 1-MCP, and three concentrations $(0.5,2.0,6.0 \%)$ for $\mathrm{CaCl}_{2}$ treatments were investigated. The preliminary results showed that $500 \mathrm{ppb}$ for 1-MCP fumigation and $2 \%$ for $\mathrm{CaCl}_{2}$ dipping were effective in delaying the discoloration and softening of cherry tomato. Thus, we choose the $500 \mathrm{ppb}$ of $1-\mathrm{MCP}$ and $2 \%$ of $\mathrm{CaCl}_{2}$ for this study.

Next, the fruits were randomly divided into four groups. Each was treated with one of the following pretreatment: (1) dipping into $2 \% \mathrm{CaCl}_{2}$ solution for $2 \mathrm{~min}$, (2) fumigating in 500ppb of 1-MCP (AgroFresh Solutions Inc., PA, USA) for $14 \mathrm{~h}$ in a $0.35 \mathrm{~m}^{3}$ airtight chamber at room temperature, (3) applying both $2 \% \mathrm{CaCl}_{2}$ and $500 \mathrm{ppb}$ of $1-\mathrm{MCP}$, and (4) control (no treatment). All treated fruits and control sample were placed in a plastic container (15 fruits/ container), and were stored in $10 \pm 1^{\circ} \mathrm{C}$ cold storage for 17 days, then transferred to $20^{\circ} \mathrm{C}$ chamber for additional four days. For parameter monitoring, three fruit containers were randomly selected every four days from each treatment unit. After sampling, half of the samples were used for physicochemical factors assessment, while the other half was prepared as the freeze sample for antioxidant activity, lycopene content and insoluble pectin content determination. 


\section{Determination of respiration rate and ethylene production}

The respiration and ethylene production rates were measured using a gas chromatograph (GC, Bruker 450-GC, Bruker Crop., Billerica, MA, USA) equipped with a flame ionization detector (FID) to measure ethylene production ( $\left.\mu \mathrm{g} \mathrm{C}_{2} \mathrm{H}_{4} / \mathrm{kg} \cdot \mathrm{h}\right)$ and a thermal conductivity detector (TCD) to measure carbon dioxide production $(\mathrm{mL} \mathrm{CO} / \mathrm{kg} \cdot \mathrm{h})$. Ten fruits from each treatment group were enclosed in $1 \mathrm{~L}$ air-tight container for $1 \mathrm{~h}$. One milliliter of headspace gas was used for injection into the GC system. During the operation, the injector and column oven were set at 110 and $70^{\circ} \mathrm{C}$, respectively, while the FID and TCD were set at 250 and $150^{\circ} \mathrm{C}$.

\section{Evaluation of fruit quality}

The surface color was determined by using a colorimeter (Minolta CR-400, Osaka, Japan) after calibration with a white tile. CIE $\mathrm{L}$, $\mathrm{a}$, and $\mathrm{b}$ values were taken on fruit equatorial axes and calculated the hue angle. The firmness of fruit was measured by using a texture analyzer (TA Plus, Lloyd Instruments, Hamshire, UK) at a rate of $2 \mathrm{~mm} / \mathrm{sec}$ with $5 \mathrm{~mm}$ diameter plunger, and expressed as Newton $(\mathrm{N})$. The rate of weight loss was determined at two-days interval and expressed as a percentage of the initial weight. The squeezed tomato juice from each treatment was used for total soluble solid (TSS) determination with a refractometer (Pocket refractometer PAL-1, Atago, Tokyo, Japan), and titratable acidity (TA) was assessed by titration of $2 \mathrm{~mL}$ juice with $0.1 \mathrm{~N}$ sodium hydroxide to an endpoint of $\mathrm{pH}$ 8.2 using an auto $\mathrm{pH}$ titrator (Titroline easy, SCHOTT Instruments, Mainz, Germany). The ratio between TSS and TA was also used to evaluate the effect of treatments upon cherry tomato.

\section{Sample preparation}

The frozen sample $(2 \mathrm{~g})$ was mixed with $70 \%$ methanol $(10 \mathrm{~mL})$ and extracted using an incubator shaker at $30^{\circ} \mathrm{C}$ for $1 \mathrm{~h}$. After extraction, the methanol layer of each sample tube was separated through centrifugation at $12,000 \mathrm{rpm}$ for 15 min at $4^{\circ} \mathrm{C}$. The supernatant layer was then collected and filtered through a $2 \mu \mathrm{m}$ of PTEF syringe filter, and employed for determination of the antioxidant activity using the 2,2-diphenyl-1-picrylhydrazyl (DPPH) assay, the 2,2'-azinobis- 3-ethylbenzothiazoline-6-sulfonic acid (ABTS) radical scavenging activity, and the total phenol content (TPC).

\section{Determination of DPPH radical scavenging activity}

The free radical-scavenging activity of the hydrophilic tomato extract was evaluated using the stable DPPH radical, according to the method of Blosis (1958). The absorbance of the sample was monitored at $515 \mathrm{~nm}$ using a microplate spectrophotometer (Epcho 2, BioTek Instrument, Inc., Winooski, VT, USA) with methanol as a reference. A Trolox calibration curve $(0-1,000 \mu \mathrm{mol}$ $\mu \mathrm{L}-1 ; \mathrm{y}=-0.0012 \mathrm{x}+0.0429 ; \mathrm{r} 2=0.992)$ was used to determine the number of $\mu \mathrm{mol}$ of Trolox per gram of fresh sample.

\section{Determination of $A B T S$ radical scavenging activity}

The ABTS radical scavenging activity of each sample was then determined according to a previous literature procedure (Re et al., 1999) with some modifications. For this purpose, the scavenging capacity was measured at $734 \mathrm{~nm}$ using a microplate spectrophotometer. A Trolox calibration curve $(0-1,000 \mu \mathrm{mol} / \mu \mathrm{L} ; \mathrm{y}=-0.0013 \mathrm{x}+$ $\left.0.0128 ; r^{2}=0.999\right)$ was used to determine the number of $\mu$ mol of Trolox per gram of fresh sample.

\section{Determination of total phenol content}

According to the method of Swine and Hillis (1959), the TPCs were determined using the Folin-Ciocalteu reagent, whereby the sample absorbance was measured at $726 \mathrm{~nm}$ using a microplate spectrophotometer. The TPCs of the fruit samples were expressed as milligrams of gallic acid equivalents (GAE) per fresh weight gram of sample using a gallic acid calibration curve $(0-500 \mu \mathrm{mol} / \mu \mathrm{L} ; \mathrm{y}=0.0076 \mathrm{x}$ - 0.0844; $\left.r^{2}=0.9956\right)$.

\section{Determination of lycopene content}

Lycopene extraction was performed on the method of Barba et al. (2006) with a slight modification. Frozen fine sample $(0.6 \mathrm{~g})$ was homogenized with $30 \mathrm{~mL}$ of hexane/ acetone/ethanol $(1: 1: 1, \mathrm{v} / \mathrm{v})$ solution and was placed on shaker for $30 \mathrm{~min}$. The extracts were centrifuged at 3,000 $\times g$ and $4^{\circ} \mathrm{C}$ for $10 \mathrm{~min}$, then added with $15 \mathrm{~mL}$ of distilled water, and shaken for $5 \mathrm{~min}$. The upper layer was transferred to new tube with wrapping aluminum foil. Finally, the 
concentration of lycopene at $503 \mathrm{~nm}$ was measured from lycopene extract using microplate spectrophotometer. Extraction solvent was used as blank and the amount of lycopene was expressed as $\mathrm{mg} / \mathrm{kg}$ fresh weight of sample.

\section{Crude cell wall extraction}

According to the method of Chatkaew and Kim (2013), crude cell wall was extracted step by step from $2 \mathrm{~g}$ of freeze-dried samples with $80 \%$ ethanol, chloroform: methanol $(1: 1, \mathrm{v} / \mathrm{v})$, acetone, and finally $20 \mathrm{mM}$ HEPES$\mathrm{NaOH}(\mathrm{pH}$ 7.0) solution containing 1 unit $/ \mathrm{mL}$ of $\alpha$ amylase. These extracted crude cell walls were used for the insoluble pectin (polyuronide) assay. For polyuronide assay, $10 \mathrm{mg}$ of crude cell wall was treated with $2 \mathrm{~mL}$ of cold sulphuric acid and incubated at room temperature for 12 hours. After incubation, the volume was made up to $25 \mathrm{~mL}$ with distilled water and vortexed.

\section{Polyuronide assay}

Based on the methods of Gross and Wang (1984), the mixture of $0.4 \mathrm{~mL}$ of the diluted sample, $0.04 \mathrm{~mL}$ of potassium sulphamate/sulpamic acid solution ( $\mathrm{pH}$ 1.6), and $2.4 \mathrm{~mL}$ of sulphuric acid containing $75 \mathrm{mM}$ sodium tetraborate was boiled at $100^{\circ} \mathrm{C}$ for $20 \mathrm{~min}$. After cooling it at room temperature for $10 \mathrm{~min}, 0.08 \mathrm{~mL}$ of $0.15 \%$ $(\mathrm{v} / \mathrm{v}) \quad m$-phenylpnenol in $0.5 \%$ sodium hydroxide was added, then it was incubated $20 \mathrm{~min}$ at room temperature. After incubation, the extract was vortexed and used to determine the content of polyuronide with multimode microplate spectrophotometer at $525 \mathrm{~nm}$. The content of polyuronide was expressed as $\mathrm{mg} / \mathrm{kg}$ dry weight of sample by using calibration curve of galacturonic acid $\left(0-400 \mu \mathrm{g} / \mathrm{mL} ; \mathrm{y}=0.1406 \mathrm{x}-0.1907 ; \mathrm{r}^{2}=0.9486\right)$.

\section{Statistical analysis}

This experiment was arranged with a completely randomized design, consisting of three pretreatment units and control. All the parameters were assessed in triplicate, and presented as means \pm standard deviation (SD). Data analysis was performed with SAS program version 9.1 (SAS Institute Inc., Cary, NC, USA). Significant differences among the treatments were taken at $p<0.05$ by using one way ANOVA, followed by Duncan's multiple range tests as a post work.

\section{Results and discussion}

\section{Respiration rate and ethylene production}

In this study, 1-MCP and $\mathrm{CaCl}_{2}$ treatments had no significant changes of the respiration rate and ethylene production in cherry tomatoes. The patterns of respiration rate and ethylene production in cherry tomatoes had just passed the peak of the climacteric phase since the initial storage (Fig. 1A) because the cherry tomatoes have reached its maturity. In observing the pattern of respiration, the rates in all treatments were similar and declined at $10^{\circ} \mathrm{C}$ storage period, except when all samples were transferred to room temperature storage and, the rates remarkably increased (Fig. 1A). Arah et al. (2015) suggested that ambient temperature promotes metabolic activities and it affects the respiration rate. Interestingly, even when the respiration rates of all
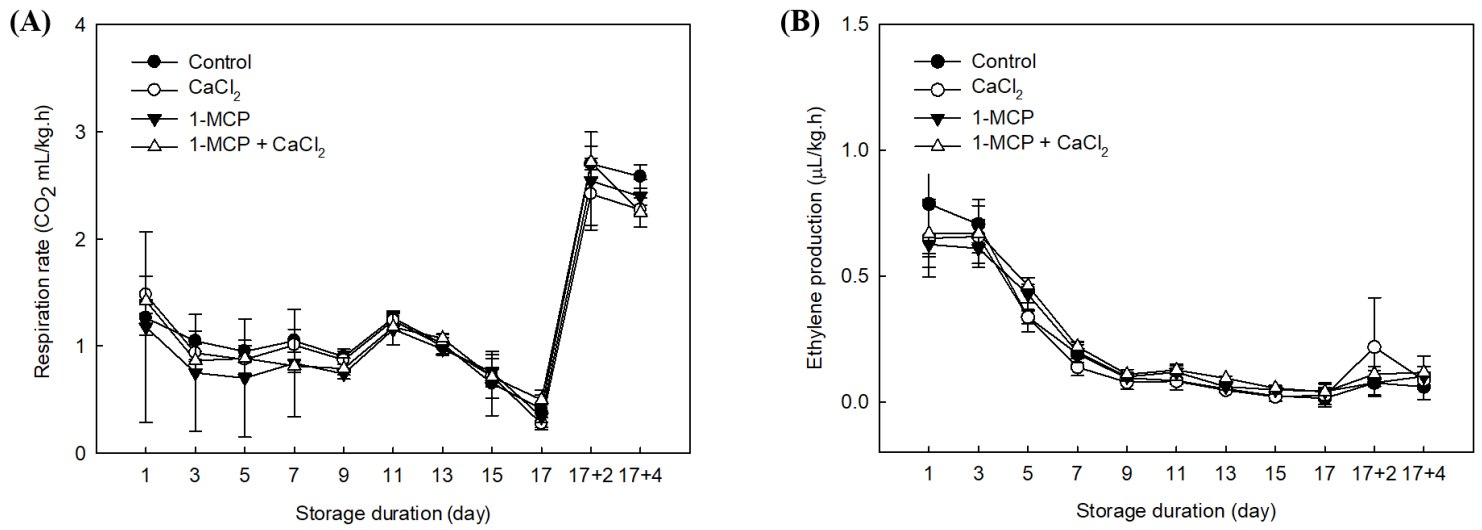

Fig. 1. Respiration rate (A) and ethylene production (B) of 'TY high $\mathrm{Q}$ ' cherry tomato fruits after treatment with $1-\mathrm{MCP}, \mathrm{CaCl}_{2}$, and $1-\mathrm{MCP}$ with $\mathrm{CaCl}_{2}$ during 17 days storage at $10 \pm 1^{\circ} \mathrm{C}$, and then transferred to $20^{\circ} \mathrm{C}$ for another $17+4$ days. 
cherry tomatoes had reached the climacteric phase, 1-MCP showed a suppression effect in the expression of respiration rate within 5 days after treatment (Fig. 1).

The ethylene productions in all treatment were gradually decreased until 17 days of storage because the full-ripe fruit were already passed a climacteric respiratory phase (Fig. 1B). However, the groups treated with $1-\mathrm{MCP}$ or a combination of $1-\mathrm{MCP}$ and $\mathrm{CaCl}_{2}$ contained lower ethylene concentrations than the control and the $\mathrm{CaCl}_{2}$-treated group until 9 days after treatment. We note that 1-MCP is a competitive inhibitor, which binds to the ethylene receptor instead of ethylene (Blankenship and Dole, 2003). In addition, exogenous 1-MCP application has been found to result in various post-harvest effects depending on the sample maturity, but its key role is as a competitive inhibitor, as mentioned above (Guillén et al., 2006; Opiyo and Ying, 2005). 1-MCP treatment of fully-ripe cherry tomatoes is therefore expected to inhibit the ethylene autocatalytic reaction.

The 1-MCP with $\mathrm{CaCl} 2$ treatment showed a slight suppression of respiration rate and ethylene production rate, especially when the treated samples were exposed to room temperature. Therefore, the expression levels of ethylene receptors after the climacteric phase can be examined further in a different study by using a combination treatment. The elevated ethylene climacteric peaks among treatments were finished because the plant material approached its full ripening stage (Fig. 1B).

\section{Assessment of physicochemical factors}

The weight loss of each tomato sample undergoing the different treatments was measured at 2 days intervals, as outlined in Fig. 2. In the case of the treatments that preserved the fruit samples, an average weight loss of $1.46 \pm 0.04 \%$ was recorded, which is lower than that measured for the control $(1.74 \pm 0.16 \%)$. More specifically, effective treatments for weight loss prevention were 1-MCP $(1.44 \pm 0.06 \%)$ and $\mathrm{CaCl}_{2}(1.44 \pm 0.04 \%)$. Although Wills and $\mathrm{Ku}$ (2002) reported that 1-MCP treatment had no effect on weight loss in ripened "Clarion" tomatoes, we found that 1-MCP treatment did indeed prevent weight loss in the fully-ripe cherry tomatoes examined herein. In addition, the ripening response to $1-\mathrm{MCP}$ in cherry tomatoes has previously been found to depend on

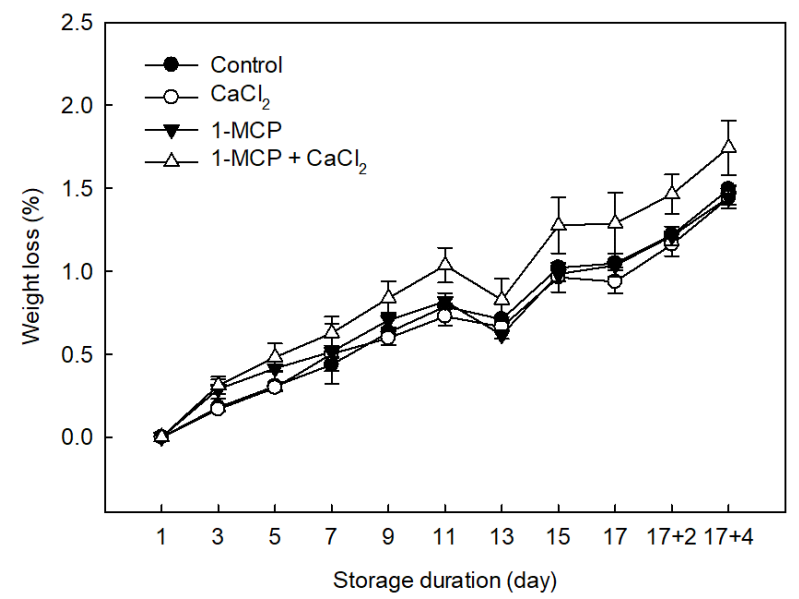

Fig. 2. Weight loss of "TY high Q" cherry tomato fruit after its treatment with $\mathrm{CaCl}_{2}, 1-\mathrm{MCP}$ and 1-MCP with $\mathrm{CaCl}_{2}$ during 17-day storage at $10^{\circ} \mathrm{C}$, then transferred to $20^{\circ} \mathrm{C}$ for another $17+4$ days.

the pretreatment conditions, such as the concentration, treatment time, and fruit maturity, and also on the subsequent storage conditions (Mir et al., 2004; Pristijono et al., 2017). Overall, previous studies have indicated that 1-MCP offers a beneficial effect in full-ripe tomato cultivars through the inhibition of ethylene production, lycopene degradation, and softening (Guillen et al., 2006; Opiyo and Ying, 2005). Similarly, $\mathrm{CaCl}_{2}$ treatment was also successful in limiting weight loss during storage due to the effects of calcium on the membrane functionality and integrity, whereby the loss of phospholipids and proteins is limited, and ion leakage is reduced (Lester and Grusak, 1999).

In Fig. 3, the firmness of cherry tomatoes under treatments was $\mathrm{CaCl}_{2}: 7.62 \pm 0.16 \mathrm{~N}, 1-\mathrm{MCP}: 7.42 \pm 0.33 \mathrm{~N}$, 1-MCP with $\mathrm{CaCl}_{2}: 7.24 \pm 0.33$, and control: $6.66 \pm 0.25 \mathrm{~N}$, respectively. The results indicate that all chemical treatments in cherry tomato had a higher firmness characteristic during storage. The maintenance of firmness in $\mathrm{CaCl}_{2}$ treatment was the best, and the possible factor is function of $\mathrm{Ca}^{2+}$ ion which binds together the strands of pectin that helps to maintain fruit firmness (Aghdama et al., 2012; Vicente et al., 2009). Therefore, $\mathrm{CaCl}_{2}$, and 1-MCP with $\mathrm{CaCl}_{2}$ treatments have calcium properties that maintain the cell wall composition of fruits compared with other treatments like 1-MCP. In general, pectin is a major component of cell wall in cherry tomato (Wakabayashi, 2000), and we evaluated the treatment performance upon the firmness through the assay 


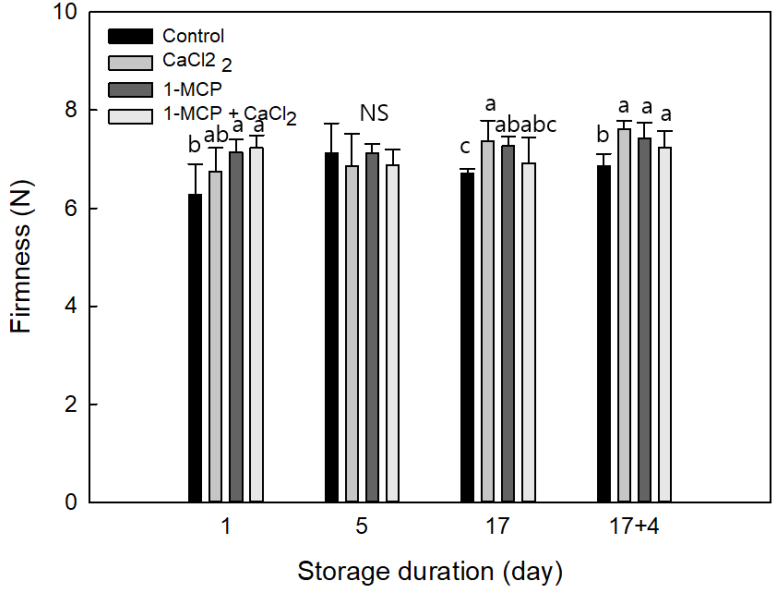

Fig. 3. Changes in the firmness of "TY high Q" cherry tomato fruits after its treatment with $\mathrm{CaCl}_{2}, 1-\mathrm{MCP}$ and 1-MCP with $\mathrm{CaCl}_{2}$ during 17 days storage at $10^{\circ} \mathrm{C}$ and transferred to $20^{\circ} \mathrm{C}$ for another $17+4$ days.

The values represented are means \pm SD of three replicates. Among the treatments, the mean bar with same lowercase letter are not significantly different by using the Duncan's multiple range test.

NS, not significant. of insoluble pectin in this study.

The contents of TSS and TA in the fruit remained relatively stable during storage (Table 1). In terms of the TSS contents, no significant differences were observed among the treated and control groups. The changes of TSS in control and all treatments had no significant differences. However, the treatments of 1-MCP and 1-MCP with $\mathrm{CaCl}_{2}$ in cherry tomatoes showed a lower reduction of TA content during storage whereas the TA contents of control and $\mathrm{CaCl}_{2}$ treated fruit were drastically declined within 5 days and 9 days after storage, respectively. It has been elucidated that the degradation of respiratory substrates, including organic acids and soluble sugars, is inhibited by exogenous 1-MCP at various ripening stages of tomato cultivars (Guillén et. Al., 2006; Opiyo and Ying, 2005). During the fruit ripening process, an increase in the TSS and decrease in organic acid content by activation of respiration metabolisms including glycolysis and citric acid cycle (TCA cycle), thus the

Table 1. Effect of $\mathrm{CaCl}_{2}, 1-\mathrm{MCP}$ and 1-MCP with $\mathrm{CaCl}_{2}$ on total soluble solids content (TSS), titratable acidity (TA) and ratio of TSS to TA of 'TY high $Q$ ' cherry tomato during 17 day storage at $10^{\circ} \mathrm{C}$, plus four days shelf-life at $20^{\circ} \mathrm{C}$

\begin{tabular}{|c|c|c|c|c|c|c|}
\hline \multirow{2}{*}{ Treatment } & \multicolumn{5}{|c|}{$10^{\circ} \mathrm{C}$} & \multirow{2}{*}{$\frac{20^{\circ} \mathrm{C}}{\text { Additional } 4 \text { days }}$} \\
\hline & 1 day & 5 days & 9 days & 13 days & 17 days & \\
\hline \multicolumn{7}{|l|}{ TSS ( ${ }^{\circ}$ Brix) } \\
\hline Control & $4.95 \pm 0.08^{1) \mathrm{Aa} 2)}$ & $4.72 \pm 0.37^{\mathrm{Aa}}$ & $4.56 \pm 0.15^{\mathrm{Ac}}$ & $4.75 \pm 0.29^{\mathrm{Aa}}$ & $4.97 \pm 0.30^{\mathrm{Aa}}$ & $4.84 \pm 0.07^{\text {Aab }}$ \\
\hline $\mathrm{CaCl}_{2}$ & $4.98 \pm 0.52^{\mathrm{ABa}}$ & $5.07 \pm 0.14^{\mathrm{Aa}}$ & $4.75 \pm 0.21^{\mathrm{Abc}}$ & $4.45 \pm 0.35^{\mathrm{Ba}}$ & $5.24 \pm 0.05^{\mathrm{Aa}}$ & $5.04 \pm 0.05^{\mathrm{Aa}}$ \\
\hline 1-MCP & $5.00 \pm 0.35^{\mathrm{Aa}}$ & $4.85 \pm 0.17^{\mathrm{Aa}}$ & $4.97 \pm 0.14^{\mathrm{Ab}}$ & $4.63 \pm 0.03^{\mathrm{Aa}}$ & $4.91 \pm 0.21^{\mathrm{Aa}}$ & $4.76 \pm 0.52^{\mathrm{Aab}}$ \\
\hline 1-MCP with $\mathrm{CaCl}_{2}$ & $4.80 \pm 0.17^{\mathrm{Ba}}$ & $4.95 \pm 0.55^{\mathrm{ABa}}$ & $5.35 \pm 0.15^{\mathrm{Aa}}$ & $4.58 \pm 0.08^{\mathrm{Ba}}$ & $4.90 \pm 0.26^{\mathrm{ABa}}$ & $4.44 \pm 0.14^{\mathrm{Bb}}$ \\
\hline \multicolumn{7}{|l|}{ TA $(\%)$} \\
\hline Control & $1.26 \pm 0.16^{\mathrm{Aa}}$ & $0.98 \pm 0.10^{\mathrm{Aab}}$ & $0.88 \pm 0.04^{\mathrm{Ab}}$ & $1.04 \pm 0.09^{\mathrm{Aa}}$ & $1.09 \pm 0.15^{\mathrm{Aa}}$ & $0.91 \pm 0.03^{\mathrm{Ab}}$ \\
\hline $\mathrm{CaCl}_{2}$ & $1.19 \pm 0.08^{\mathrm{Aa}}$ & $1.17 \pm 0.11^{\mathrm{Aa}}$ & $1.07 \pm 0.07^{\mathrm{Aa}}$ & $0.99 \pm 0.22^{\mathrm{Aa}}$ & $1.09 \pm 0.03^{\mathrm{Aa}}$ & $1.00 \pm 0.08^{\mathrm{Aa}}$ \\
\hline 1-MCP & $1.21 \pm 0.15^{\mathrm{Aa}}$ & $1.14 \pm 0.02^{\mathrm{ABab}}$ & $1.03 \pm 0.09^{\mathrm{Ba}}$ & $1.13 \pm 0.04^{\mathrm{ABa}}$ & $1.10 \pm 0.06^{\mathrm{ABa}}$ & $1.14 \pm 0.09^{\mathrm{ABba}}$ \\
\hline 1-MCP with $\mathrm{CaCl}_{2}$ & $1.14 \pm 0.06^{\mathrm{Aa}}$ & $0.99 \pm 0.12^{\mathrm{Bb}}$ & $1.08 \pm 0.04^{\mathrm{Aba}}$ & $1.11 \pm 0.06^{\mathrm{ABa}}$ & $1.11 \pm 0.11^{\mathrm{ABa}}$ & $1.11 \pm 0.10^{\mathrm{Aba}}$ \\
\hline \multicolumn{7}{|l|}{ TSS/TA } \\
\hline Control & $4.55 \pm 0.71^{\mathrm{Aa}}$ & $4.79 \pm 0.15^{\mathrm{Aab}}$ & $5.18 \pm 0.43^{\mathrm{Aa}}$ & $4.60 \pm 0.56^{\mathrm{Aa}}$ & $4.63 \pm 0.38^{\mathrm{Aa}}$ & $5.29 \pm 0.26^{\mathrm{Aa}}$ \\
\hline $\mathrm{CaCl}_{2}$ & $4.49 \pm 0.64^{\mathrm{Aa}}$ & $4.35 \pm 0.50^{\mathrm{Ab}}$ & $4.45 \pm 0.46^{\mathrm{Aa}}$ & $4.61 \pm 0.72^{\mathrm{Aa}}$ & $4.81 \pm 0.10^{\mathrm{Aa}}$ & $5.04 \pm 0.38^{\mathrm{Aab}}$ \\
\hline 1-MCP & $4.18 \pm 0.56^{\mathrm{Aa}}$ & $4.27 \pm 0.05^{\mathrm{Ab}}$ & $4.87 \pm 0.47^{\mathrm{Aa}}$ & $4.10 \pm 0.11^{\mathrm{Aa}}$ & $4.46 \pm 0.14^{\mathrm{Aa}}$ & $4.19 \pm 0.60^{\mathrm{Ab}}$ \\
\hline 1-MCP with $\mathrm{CaCl}_{2}$ & $4.21 \pm 0.13^{\mathrm{Ba}}$ & $5.20 \pm 0.58^{\mathrm{Aa}}$ & $4.95 \pm 0.32^{\mathrm{Aa}}$ & $4.12 \pm 0.26^{\mathrm{Ba}}$ & $4.40 \pm 0.23^{\mathrm{Ba}}$ & $4.02 \pm 0.32^{\mathrm{Bb}}$ \\
\hline
\end{tabular}

${ }^{1)}$ Values represented are mean $\pm \mathrm{SD}$ of three replicates.

${ }^{2}$ Within each parameter, the means in the columns (storage interval) followed by the same lowercase letter and means in the rows (treatment) followed by the same uppercase letter are not significantly different by using Duncan's multiple range test $(\mathrm{p}<0.05)$. 
(TSS/TA) ratio become an indicator of fruit maturity (Will et al., 1981). In this study, we also found that the inhibition of decrease of TA in full-ripe cherry tomatoes were affected by $1-\mathrm{MCP}$ with $\mathrm{CaCl}_{2}$ as well as only 1-MCP treatment. Additionally, the TSS/TA ratio showed significant differences between control and all treatments. The lowest and highest TSS/TA ratios in fruits were observed in 1-MCP with $\mathrm{CaCl}_{2}$ treatment $(4.02 \pm 0.32)$ and control $(5.29 \pm 0.26)$, respectively. Interestingly, the 1-MCP with $\mathrm{CaCl}_{2}$ treatment showed a reducing effect of the TSS/TA ratio in full-ripe cherry tomato during storage (Table 1).

The external characteristic used to assess the ripening index is the change in skin color from green to red (Lopez Camelo and Gomez, 2004). As shown in Fig. 4, all treatments exhibited the similar patterns as an increase the level of $a^{*}$ value during storage period. The initial level of $\mathrm{a}^{*}$ value $(16.8 \pm 0.8)$ in control was immediately approached to the highest level $(21.0 \pm 1.4)$ within five days of initial storage (Fig. 4B). In $\mathrm{CaCl}_{2}$ treatment, the level of a* value was also increased and reached the high level $(17.8 \pm 2.6)$ at 9 days after storage. However, 1-MCP, and 1-MCP with $\mathrm{CaCl}_{2}$ treated fruit were still maintained the light red color until 17 days after storage with maximum $\mathrm{a}^{*}$ value as $16.8 \pm 1.9$ and $15.4 \pm 2.1$, respectively. In these observations after storage at $10^{\circ} \mathrm{C}, 1-\mathrm{MCP}$ with $\mathrm{CaCl}_{2}$ treatment showed more effective in delaying the discoloration as dark red color (Fig. 4A). The result value of $\mathrm{a}^{*}$ in fruit during the storage of $10^{\circ} \mathrm{C}$ and $20^{\circ} \mathrm{C}$ was similar to the result of hue angle. Lowest level of hue angle along the storage duration was found in the control (Fig. 4B). In this study, when the control was approached to over-ripe stages, the value of $\mathrm{a}^{*}$ were recorded more than 20 (Fig. 4). The value of $a^{*}$ in control fruit was gradually increased until 21.5 value at 5
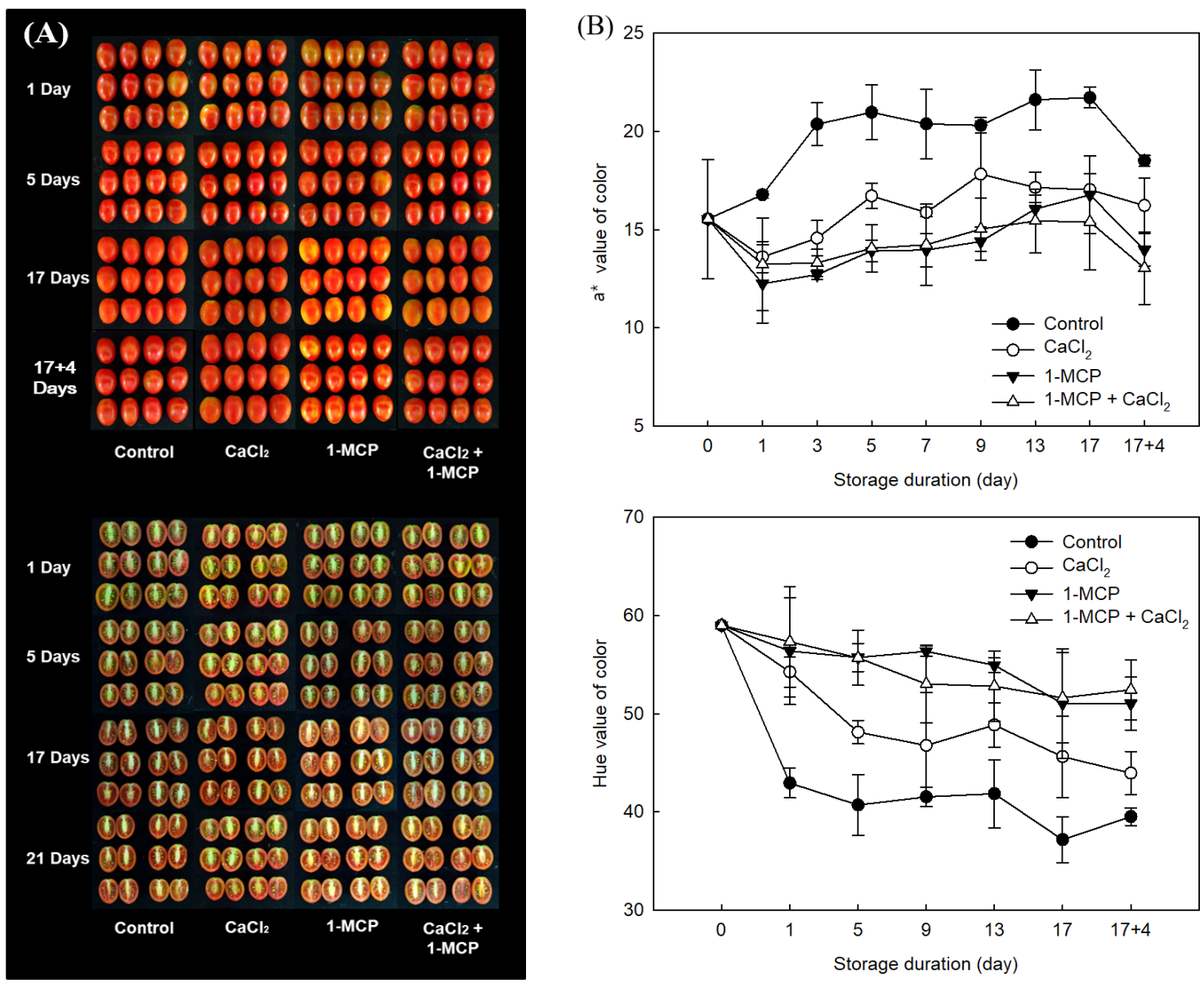

Fig. 4. Effect of the treatment on "TY high Q" cherry tomato (A) phenotypic observation of tomato fruit ripening process and (B) changes in color $\left(\mathrm{a}^{*}\right.$ value and Hue angle) during 17 days storage at $10^{\circ} \mathrm{C}$, then transferred to $20^{\circ} \mathrm{C}$ for another $17+4$ days. 
days after treatment, but the value in $1-\mathrm{MCP}$ with $\mathrm{CaCl}_{2}$ treated fruit was increased until 15.1 value for whole storage. Thus, 1-MCP with $\mathrm{CaCl}_{2}$ might be maintained the preference color of cherry tomato as the full-ripe fruit more than 12 days compared to control fruit. In this study, the combination treatment using 1-MCP and $\mathrm{CaCl}_{2}$ might be revealed a positive effect on postharvest quality by showing the lowest changes of weight loss, TSS/TA ratio, firmness, and color in full-ripe cherry tomatoes.

\section{Antioxidant activities}

According to the analysis of variance, the positive effect of treatments upon the antioxidant activities of full-ripe cherry tomato was significant $(\mathrm{p}<0.05)$. Overall, increases in the antioxidant activities and TPCs were observed for all treatments (Tables 2 and 3). In this study, the $2 \% \mathrm{CaCl}_{2}$ treated fruit were maintained the increase of antioxidant activities in comparison with 1-MCP, and 1-MCP with $\mathrm{CaCl}_{2}$ treated fruits during storage (Table 2). Mansourbahmani et al. (2017) also found that $2 \%$ of $\mathrm{CaCl}_{2}$ had a positive preservation effect of phenolic compound during storage. Furthermore, the TPCs of the control and the $\mathrm{CaCl}_{2}$ treatment in cherry tomatoes were found to be positively correlated to the DPPH radical scavenging activity $(\mathrm{r}=$ 0.894 for $\mathrm{CaCl}_{2}$ treatment, 0.833 for the control) and ABTS ( $\mathrm{r}=0.725$ for $\mathrm{CaCl}_{2}$ treatment, 0.778 for the control, Table $3)$. Normally, an increase in the antioxidant activity during cold storage could be attributed to ripening and the metabolism of phenolic compounds, mainly flavonoids (Javanmardi and Kubota, 2006; Shahidi and Naczk, 1995).

In general, the antioxidant activity is significantly influenced by the maturity stage of the fruit, although hydrophilic antioxidant activities tend to remain relatively stable over the advanced ripening stages of tomatoes (Cano et al., 2003; Martinez-Valverde et al., 2002). Although Ilic et al. (2013) also reported that 1-MCP treatment reduced the

Table 2. Effect of $\mathrm{CaCl}_{2}, 1-\mathrm{MCP}$ and 1-MCP with $\mathrm{CaCl}_{2}$ on DPPH, ABTS, and TPC of 'TY high Q' cherry tomato during 17-day storage at $10^{\circ} \mathrm{C}$, plus four days shelf-life at $20^{\circ} \mathrm{C}$

\begin{tabular}{|c|c|c|c|c|c|c|}
\hline \multirow{2}{*}{ Treatment } & \multicolumn{5}{|c|}{$10^{\circ} \mathrm{C}$} & \multirow{2}{*}{$\frac{20^{\circ} \mathrm{C}}{\text { Additional } 4 \text { days }}$} \\
\hline & 1 day & 5 days & 9 days & 13 days & 17 days & \\
\hline \multicolumn{7}{|c|}{ DPPH radical scavenging ( $\mu \mathrm{mol} / \mathrm{g} \mathrm{FW})$} \\
\hline Control & $1.48 \pm 0.12^{1) \mathrm{Ca} 2)}$ & $1.64 \pm 0.27^{\mathrm{BCa}}$ & $1.87 \pm 0.06^{\mathrm{ABa}}$ & $1.98 \pm 0.11^{\mathrm{Aa}}$ & $1.58 \pm 0.04^{\mathrm{BCa}}$ & $1.77 \pm 0.28^{\mathrm{ABCa}}$ \\
\hline $\mathrm{CaCl}_{2}$ & $1.64 \pm 0.25^{\mathrm{Aa}}$ & $1.76 \pm 0.22^{\mathrm{Aa}}$ & $1.97 \pm 0.25^{\mathrm{Aa}}$ & $1.90 \pm 0.09^{\mathrm{Aa}}$ & $1.74 \pm 0.04^{\mathrm{Aa}}$ & $2.02 \pm 0.20^{\mathrm{Aa}}$ \\
\hline 1-MCP & $1.49 \pm 0.21^{\mathrm{Aa}}$ & $1.55 \pm 0.12^{\mathrm{Aa}}$ & $1.61 \pm 0.32^{\mathrm{Aa}}$ & $1.68 \pm 0.12^{\mathrm{Ab}}$ & $1.55 \pm 0.09^{\mathrm{Aa}}$ & $1.66 \pm 0.17^{\mathrm{Aa}}$ \\
\hline 1-MCP with $\mathrm{CaCl}_{2}$ & $1.69 \pm 0.15^{\mathrm{ABa}}$ & $1.49 \pm 0.26^{\mathrm{Ba}}$ & $1.98 \pm 0.11^{\mathrm{Aa}}$ & $1.62 \pm 0.13^{\mathrm{Bb}}$ & $1.66 \pm 0.21^{\mathrm{ABa}}$ & $1.71 \pm 0.14^{\mathrm{ABa}}$ \\
\hline \multicolumn{7}{|c|}{ ABTS radical scavenging ( $\mu \mathrm{mol} / \mathrm{g} \mathrm{FW})$} \\
\hline Control & $1.95 \pm 0.12^{\mathrm{Aa}}$ & $1.90 \pm 0.17^{\mathrm{Aa}}$ & $2.06 \pm 0.22^{\mathrm{Aab}}$ & $2.10 \pm 0.19^{\mathrm{Aab}}$ & $2.17 \pm 0.07^{\mathrm{Aa}}$ & $2.16 \pm 0.27^{\mathrm{Aab}}$ \\
\hline $\mathrm{CaCl}_{2}$ & $2.05 \pm 0.21^{\mathrm{Aa}}$ & $2.10 \pm 0.22^{\mathrm{Aa}}$ & $2.11 \pm 0.15^{\mathrm{Aab}}$ & $2.25 \pm 0.17^{\mathrm{Aa}}$ & $2.16 \pm 0.07^{\mathrm{Aa}}$ & $2.37 \pm 0.11^{\mathrm{Aa}}$ \\
\hline 1-MCP & $1.98 \pm 0.30^{\mathrm{Aa}}$ & $2.10 \pm 0.10^{\mathrm{Aa}}$ & $1.79 \pm 0.29^{\mathrm{Ab}}$ & $1.86 \pm 0.18^{\mathrm{Ab}}$ & $1.97 \pm 0.09^{\mathrm{Aa}}$ & $1.90 \pm 0.06^{\mathrm{Ab}}$ \\
\hline 1-MCP with $\mathrm{CaCl}_{2}$ & $2.25 \pm 0.20^{\mathrm{Aa}}$ & $2.02 \pm 0.27^{\mathrm{Aa}}$ & $2.20 \pm 0.09^{\mathrm{Aa}}$ & $2.02 \pm 0.06^{\mathrm{Aab}}$ & $2.17 \pm 0.21^{\mathrm{Aa}}$ & $2.08 \pm 0.11^{\text {Aab }}$ \\
\hline \multicolumn{7}{|c|}{ Total phenol content $(\mathrm{mg} / \mathrm{g} \mathrm{FW})$} \\
\hline Control & $0.38 \pm 0.04^{\mathrm{Aa}}$ & $0.38 \pm 0.04^{\mathrm{Aa}}$ & $0.42 \pm 0.03^{\mathrm{Aa}}$ & $0.42 \pm 0.01^{\mathrm{Aa}}$ & $0.39 \pm 0.02^{\mathrm{Aa}}$ & $0.40 \pm 0.06^{\mathrm{Aa}}$ \\
\hline $\mathrm{CaCl}_{2}$ & $0.37 \pm 0.05^{\mathrm{Aa}}$ & $0.41 \pm 0.04^{\mathrm{Aa}}$ & $0.43 \pm 0.04^{\mathrm{Aa}}$ & $0.39 \pm 0.02^{\text {Aab }}$ & $0.40 \pm 0.02^{\mathrm{Aa}}$ & $0.42 \pm 0.03^{\mathrm{Aa}}$ \\
\hline 1-MCP & $0.37 \pm 0.05^{\mathrm{Aa}}$ & $0.39 \pm 0.02^{\mathrm{Aa}}$ & $0.38 \pm 0.06^{\mathrm{Aa}}$ & $0.36 \pm 0.02^{\mathrm{Ab}}$ & $0.36 \pm 0.02^{\mathrm{Aa}}$ & $0.36 \pm 0.01^{\mathrm{Aa}}$ \\
\hline 1-MCP with $\mathrm{CaCl}_{2}$ & $0.39 \pm 0.04^{\mathrm{Aa}}$ & $0.35 \pm 0.04^{\mathrm{Aa}}$ & $0.41 \pm 0.03^{\mathrm{Aa}}$ & $0.35 \pm 0.01^{\mathrm{Ab}}$ & $0.37 \pm 0.03^{\mathrm{Aa}}$ & $0.37 \pm 0.02^{\mathrm{Aa}}$ \\
\hline
\end{tabular}

\footnotetext{
${ }^{1)}$ Values represented are mean $\pm \mathrm{SD}$ of three replicates.

${ }^{2}$ Within each parameter, the means in the columns (storage interval) followed by the same lowercase letter and means in the rows (treatment) followed by the same uppercase letter are not significantly different by using Duncan's multiple range test $(p<0.05)$.
} 
Table 3. Correlation coefficients among DPPH, ABTS, and TPC of chenry tomato fruit treated with $\mathrm{CaCl}_{2}, 1-\mathrm{MCP}$, and $1-\mathrm{MCP}$ with $\mathrm{CaCl}_{2}$ and untreated (Control)

\begin{tabular}{|c|c|c|c|c|c|c|c|c|}
\hline \multirow{2}{*}{ Assay } & \multicolumn{2}{|c|}{ Control } & \multicolumn{2}{|c|}{$\mathrm{CaCl}_{2}$} & \multicolumn{2}{|c|}{ 1-MCP } & \multicolumn{2}{|c|}{ 1-MCP with $\mathrm{CaCl}_{2}$} \\
\hline & DPPH & ABTS & DPPH & ABTS & DPPH & ABTS & DPPH & ABTS \\
\hline ABTS & $0.714^{* 1)}$ & 1.00 & $0.839^{*}$ & 1.00 & $0.556^{* *}$ & 1.00 & $0.600^{*}$ & 1.00 \\
\hline Total phenol content & $0.833^{* *}$ & $0.779^{* *}$ & $0.894^{* *}$ & $0.725^{* *}$ & $0.603^{*}$ & $0.523^{*}$ & $0.728^{*}$ & $0.634^{*}$ \\
\hline
\end{tabular}

${ }^{1)^{*}}$ Significant at the $5 \%$ level; ${ }^{* *}$ Significant at the $1 \%$ level.

lipophilic antioxidant activity of the pink and light red tomato fruit, but the hydrophilic antioxidant activity remained similar to condition before treatment. In this study, the antioxidant activities in the 1-MCP, and 1-MCP with $\mathrm{CaCl}_{2}$ treated fruit remained more stable than that of control fruit, even when the cherry tomatoes as the plant material were already approached to full-ripe maturity before treatment. These results therefore suggest that post-harvest treatment with 1-MCP, and 1-MCP with $\mathrm{CaCl}_{2}$ could be considered effective for prolonging the shelf lives of cherry tomatoes at the commercial mature stage.

\section{Lycopene content}

In this study, the cherry tomatoes tended to have reached the nearly red maturity stage prior to treatment, with an average hue angle of $59.7 \pm 1.33$. Therefore, the rapidly increasing rate of lycopene content in each treatment was found at the initial day of storage, and the rate changed and became slower at five days after storage. A significant difference in lycopene content was observed among treatments, particularly in the control and treatments. The highest lycopene content was found in control fruit and its value of lycopene content $(34.9 \pm 4.0 \mathrm{mg} / \mathrm{g}$ fresh weight) was higher than $\mathrm{CaCl}_{2}(29.3 \pm 3.2 \mathrm{mg} / \mathrm{g}$ fresh weight), 1-MCP (27.9 $\pm 2.4 \mathrm{mg} / \mathrm{g}$ fresh weight) and 1-MCP with $\mathrm{CaCl}_{2}$ treated fruit $(25.1 \pm 4.6 \mathrm{mg} / \mathrm{g}$ fresh weight) at the end of storage. For 9 days after storage, the lycopene contents in control and $\mathrm{CaCl}_{2}$ treated fruit were drastically expressed more than 1-MCP and 1-MCP 1ith $\mathrm{CaCl}_{2}$ treated fruit (Fig. 5). The 1-MCP with $\mathrm{CaCl}_{2}$ showed the best-inhibited effect in the accumulation of lycopene content, followed by 1-MCP in second place (Fig. 5). The 1-MCP with $\mathrm{CaCl}_{2}$ treatment under the $10^{\circ} \mathrm{C}$ storage condition is an effective method to maintain the discoloration of fruit pericarp because that treatment inhibited the accumulation of lycopene content,

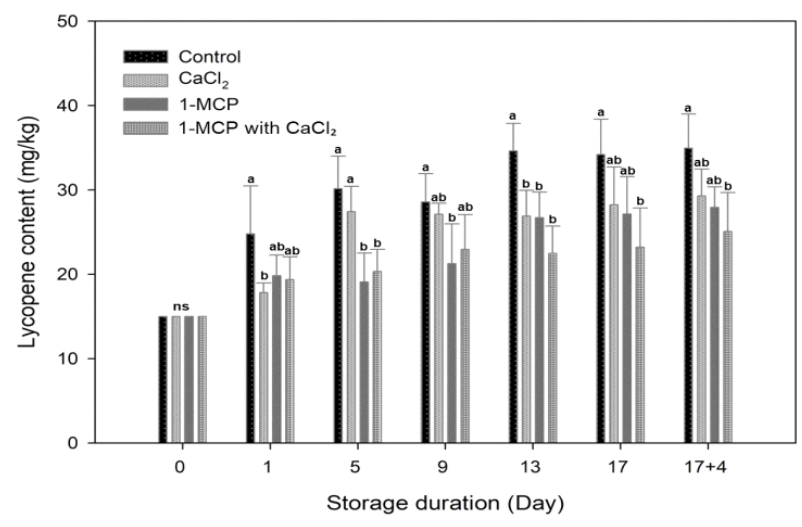

Fig. 5. The lycopene content of "TY high Q" cherry tomato fruit after its treatment with $\mathrm{CaCl}_{2}, 1-\mathrm{MCP}$ and 1-MCP with $\mathrm{CaCl}_{2}$ during 17-day storage at $10^{\circ} \mathrm{C}$ and transferred to $20^{\circ} \mathrm{C}$ for another $17+4$ days.

The values represented are mean \pm SD of three replicates. Among the treatments, the mean bar with same lowercase letter are not significantly different by using the Duncan's test $(\mathrm{p}<0.05)$.

and lengthened the ripening process of tomato (Fig. 4 and 5). It has also been reported in the literature that the accumulation of lycopene requires a continuous ethylene supply, and that $\mathrm{CaCl}_{2}$ and 1-MCP inhibit the accumulation of lycopene indirectly by preventing the build-up of ACC oxides, ethylene receptors, and the mRNA responsible for the expression of ACC synthase in tomato fruits (Hoeberichts et al., 2002; Lee et al., 2010; Opiyo and Ying, 2005). Indeed, $\mathrm{CaCl}_{2}$ has been previously employed to maintain the firmness of apples and oranges, among other fruits (Vicente et al., 2009; Aghdama et al., 2012). Our results therefore indicate that the treatment of fully-ripe cherry tomatoes with the combination of 1-MCP and $\mathrm{CaCl}_{2}$ can block the degradation of lycopene and other pigments.

The redness level of $a^{*}$ value correlated positively with the lycopene content in this studied samples $\left(\mathrm{r}^{2}=0.615\right)$. At $10^{\circ} \mathrm{C}$ stored fruits, the pattern of color $\mathrm{a}^{*}$ value changes among treatments was similar to the accumulation of lycopene 
content, direction of $\mathrm{a}^{*}$ value changes (Green to red) and pattern of lycopene accumulation oriented appositively; color value turned downward and lycopene content continued upward, during the additional four days of $20^{\circ} \mathrm{C}$ storage (Fig. 4 and 5). That result indicated that the changes along the green to red axis $\left(a^{*}\right)$ are so big that mask other two parameters changes and lead to misleading results under normal ripening condition (Lopez Camelo and Gomez, 2004). At the beginning of storage, the synthesis of lycopene builds up rapidly, and the rate becomes stable after 13 days storage to until the end of storage period (Fig. 5). Although lycopene synthesis is predominant between 12 and $32^{\circ} \mathrm{C}$ (Leoni, 1992), there was no significant difference of lycopene content from each treatment during changes in storage temperature from 10 to $20^{\circ} \mathrm{C}$. Because all stored fruits proceed according to the ripening process and reach the fully ripened stage, thus a synthesis of lycopene condition became a stationary state. However, Choi et al. (2010) mentioned that lycopene content decreases in over-ripe tomatoes.

\section{Insoluble pectin content}

Pectin is major components in cherry tomato, and its level decreases as the ripening process progresses (Wakabayashi, 2000). During the storage, concentration of insoluble pectin level in control decreased gradually and a clear significant difference between treated fruit and control fruit was found at 5 days after storage (Fig. 6). Both $\mathrm{CaCl}_{2}$ and 1-MCP reagents were effective in maintaining the insoluble pectin concentration.

In $\mathrm{CaCl}_{2}$ treatment, a function of calcium is to link uronic acid groups through $\mathrm{Ca}^{2+}$ ions to strengthen the cell wall integrity and cell to cell cohesion (Lionetti et al., 2010; Sams et al., 1993), and to maintain the insoluble pectin concentration. The polyuronides solubilization during the ripening is correlated with the polygalacturonase (PG) activity that corresponds to the softening of fruit (Huber,1983; Smith et al.,1990; Wakabayashi et al., 2000). Brummell and Labavitch (1997) reported that PG-mediated polyuronide depolymerization oriented in reducing the fruit integrity and firmness at the advanced stage of ripening. As a 1-MCP treatment, 1-MCP directly inhibits the ethylene-mediated cell wall degrading enzyme activity like a PG (Mostofi et al., 2003). Therefore, 1-MCP with $\mathrm{CaCl}_{2}$ treatment maintained

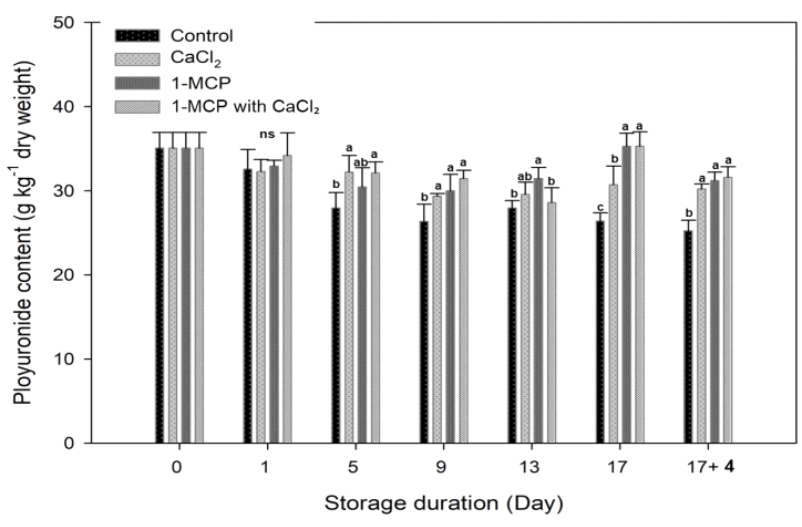

Fig. 6. Polyuronide (insoluble pectin) content of cellwall from "TY high Q" cherry tomato fruit after its treatment with $\mathrm{CaCl}_{2}, 1-\mathrm{MCP}$ and 1-MCP with $\mathrm{CaCl}_{2}$ during 17-day storage at $10^{\circ} \mathrm{C}$ and then transferred to $20^{\circ} \mathrm{C}$ for another $17+4$ days.

The values represented are the mean $\pm \mathrm{SD}$ of three replicates. Among the treatments, the mean bar with same lowercase letter are not significantly different by using the Duncan's multiple range test $(p<0.05)$.

high polyuronide content at the 9,17 and $17+4$ days after storage, but there was no significant difference with other treatments.

In conclusion, overall, 1-MCP and 1-MCP with $\mathrm{CaCl}_{2}$ treated fruits were more effective in inhibiting the pericarp discoloration, maintaining the antioxidant activities and bioactive compound content, and insoluble pectin content compared to control and $\mathrm{CaCl}_{2}$ treated fruits. There was no significant different in respiration and ethylene production rate among treatments, but the $1-\mathrm{MCP}$ with $\mathrm{CaCl}_{2}$ treatment showed a slight suppression of respiration rate and ethylene production at $20^{\circ} \mathrm{C}$. Especially, 1-MCP with $\mathrm{CaCl}_{2}$ treatment had a synergic effect to retract the color and antioxidant activities, reduce the physicochemical, inhibit the lycopene accumulation, and delay the disruption of cell wall structure. In further, we should to conduct microbial analysis of cherry tomatoes after chemical treatments above mentioned.

\section{Acknowledgement}

This study was supported by the "2019 KoRAA Longterm Training Program" and "RDA project (project number: PJ014368032020)" of Rural Development Administration (RDA), Republic of Korea. The corresponding author (S. Lim) was funded and supported by the "2020 RDA Fellowship Program of National Institute of Horticultural and Herbal Science", RDA, Republic of Korea, respectively. 


\section{Conflict of interests}

The authors declare no potential conflict of interest.

\section{ORCID}

Sooyeon Lim https://orcid.org/0000-0002-8929-3377

\section{References}

Aghdam MS, Hassanpouraghdam MB, Paliyath G, Farmani B. The language of calcium in postharvest life of fruits, vegetables and flowers. Sci Hortic, 144, 102- 115 (2012)

Arah IK, Ahorbo GK, Anku EK, Kumah EK, Amaglo H. Postharvest handling practices and treatment methods for tomato handlers in developing countries: A mini review. Adv Agric, 2016, 6436945 (2016)

Arah IK, Kumah EK, Anku EK, Amaglo H. An overview of post-harvest losses in tomato production in Africa: Causes and possible prevention strategies. J Bio Agri Healthcare, 5, 78-88 (2015)

Awang YB, Chuni SH, Mohamed MTM, Hafiza Y, Mohamad RB. Polygalacturonase and pectin methylesterase activities of $\mathrm{CaCl}_{2}$ treated red-freshed dragon fruit (Hylocereus polyrhizus) harvested at different maturity. Am J Agric Biol Sci, 8, 167-172 (2013)

Barba AIO, Hurtado MC, Mata MCS, Ruiz VF, de Tejada MLS. Application of a UV-vis detection-HPLC method for a rapid determination of lycopene and $\beta$-carotene in vegetables. Food Chem, 95, 328-336 (2006)

Batu A, Thompson AK. Effects of modified atmosphere packaging on post harvest qualities of pink tomatoes. Turk J Agric For, 22, 365-372 (1998)

Blankenship SM, Dole JM. 1-Methylcyclopropene: A review. Postharvest Biol Technol, 28, 1-25 (2003)

Blois MS. Antioxidant determinations by the use of stable free radical. Nature, 181, 1199-2000 (1958)

Brummell DA, Labavitch JM. Effect of antisense suppression of endopolygalacturonase activity on polyuronide molecular weight in ripening tomato fruit and in fruit homogenates. Plant Physiol, 115, 717-725 (1997)

Cano A, Acosta M, Arnao MB. Hydrophilic and lipophilic antioxidant activity changes during on-vine ripening of tomatoes (Lycopersicon esculentum Mill.). Postharvest
Biol Technol, 28, 59-65 (2003)

Chatkaew A, Kim J. Correlations among disease severity, firmness, minerals, and cell wall composition in radish (Raphanus sativus L.) and baemoochae ( $\times$ Brassicoraphanus) roots in relation to tissue maceration by Pectobacterium carotovorum. Hort Environ Biotechnol, 54, 346-356 (2013)

Choi SH, Lee SH, Kim HJ, Lee IS, Kozukue N, Levin CE, Friedman M. Changes in free amino acid, phenolic, chlorophyll, carotenoid, and glycoalkaloid contents in tomatoes during 11 stages of growth and inhibition of cervical and lung human cancer cells by green tomato extracts. J Agric Food Chem, 58, 7547-7556 (2010)

Cliff M, Lok S, Lu C, Toivonen PMA. Effect of 1methylcyclopropene on the sensory, visual, and analytical quality of greenhouse tomatoes. Postharvest Biol Technol, 53, 11-15 (2009)

Genanew T. Effect of post harvest treatment on storage behavior and quality of tomato of fruit. World J Agric Sci, 9, 29-37 (2013).

Giudice RD, Raiola A, Tenore GC, Frusciante L, Barone A, Monti DM, Rigano MM. Antioxidant bioactive compounds in tomato fruits at different ripening stages and their effects on normal and cancer cells. J Funct Foods, 18, 83-94 (2015)

Gross KC, Wang CY. Compositional changes in cell wall polysaccharides from chilled and non-chilled cucumber fruit. Phytochemistry, 23, 1575-1578 (1984)

Guillen F, Castillo S, Zapata PJ, Martinez-Romero D, Valero D, Serrano M. Efficacy of 1-MCP treatment in tomato fruit 2. Effect of cultivar and ripening stage at harvest. Postharvest Biol Technol, 42, 235-242 (2006)

Hoeberichts FA, Van Der Plas LHW, Woltering EJ. Ethylene perception is required for the expression of tomato ripening-related genes and associated physiological changes even at advanced stages of ripening. Postharvest Biol Technol, 26, 125-133 (2002)

Huber DJ. The role of cell wall hydrolases in fruit softening. Hortic Rev, 5, 169-219 (1983)

Ilic ZS, Marinkovic D, Trajkovic R, Sunic L, Perzelan Y, Alkalai-Tuvia S, Fallik E. Effect of 1-methylcyclopropene on the antioxidant capacity and postharvest quality of tomato fruit. Afr J Biotechnol, 12, 547-553 (2013)

Javanmardi J, Kubota C. Variation of lycopene, antioxidant 
activity, total solute solids and weight loss of tomato during postharvest storage. Postharvest Biol Technol, 41, 151-155 (2006)

Kader AA, Morris LL, Stevens MA, Albright-Holton M. Composition and flavor quality of fresh market tomatoes as influenced by some postharvest handling procedures. J Amer Soc Hort Sci, 103, 6-13 (1978)

Krumbein A, Peters P, Brückner, B. Flavour compounds and a quantitative descriptive analysis of tomatoes (Lycopersicon esculentum Mill.) of different cultivars in short-term storage. Postharvest Biol Technol, 32, 15-28 (2004)

Lee YS, Chung DS, Harte BR, Shin JM. Effect of 1methylcyclopropene (1-MCP) treatment on the quality characteristics and pigmentation of tomatoes fruit (Lycopersicon esculentum Mill). Kor J Hort Sci Technol, 28, 600-608 (2010)

Leoni C. Industrial quality as influenced by crop management. Acta Hortic, 301, 177-184 (1992)

Lester GE, Grusak MA. Postharvest application of calcium and magnesium to honeydew and netted muskmelons: Effects on tissue ion concentrations, quality, and senescence. J Amer Soc Hort Sci, 124, 545-552 (1999)

Lionetti V, Francocci F, Ferrari S, Volpi C, Bellincampi D, Galletti R, D’Ovidio R, De Lorenzo G, Cervone F. Engineering the cell wall by reducing de-methyl-esterified homogalacturonan improves saccharification of plant tissues for bioconversion. Proc Natl Acad Sci, 107, 616621 (2010)

Lopez Camelo AF, Gomez PA. Comparison of color indexes for tomato ripening. Hortic Bras, 22, 534-537 (2004)

Luengwilai K, Beckles DM, Saltveit M. Chilling-injury of harvested tomato (Solanum lycopersicum L.) cv. MicroTom fruit is reduced by temperature pre-treatments. Postharvest Biol Technol, 63, 123-128 (2012)

Lurie S, Klein JD. Ripening characteristics of tomatoes stored at $12^{\circ} \mathrm{C}$ and $2{ }^{\circ} \mathrm{C}$ following a prestorage heat treatment. Sci Hortic, 51, 55-64 (1992)

Lurie S. Stress physiology and latent damage. In: Postharvest Handling: A Systems Approach, $2^{\text {nd }}$ Ed, Florkowski WJ, Shewfelt RL, Brueckner B, Prussia SE (Editors), Academic Press, Cambridge, MA, USA, p 443-459 (2009)

Malundo TMM, Shewfelt RL, Scott JW. Flavor quality of fresh tomato (Lycopersicon escelentum Mill.) as affected by sugar and acid levels. Postharvest Biol Technol, 6, 103-110 (1995)

Mansourbahmani S, Ghareyazie B, Kalatejari S, Mohammadi RS, Zarinnia V. Effect of post-harvest UV-C irradiation and calcium chloride on enzymatic activity and decay of tomato (Lycopersicon esculentum L.) fruit during storage. J Integr Agric, 16, 2093-2100 (2017)

Martinez-Valverde I, Periago MJ, Provan G, Chesson A. Phenolic compounds, lycopene and antioxidant activity in commercial varieties of tomato (Lycopersicum esculentum). J Sci Food Agric, 82, 323-330 (2002)

Mir N, Canoles M, Beaudry R, Baldwin E, Mehla CP. Inhibiting tomato ripening with 1-methylcyclopropene. $\mathrm{J}$ Amer Soc Hort Sci, 129, 112-120 (2004)

Mostofi Y, Toivonen PMA, Lessani H, Babalar M, Lu CW. Effects of 1-methylcyclopropene on ripening of greenhouse tomatoes at three storage temperatures. Postharvest Biol Technol, 27, 285-292 (2003)

Njoroge CK, Kerbel EL, Briskin DP. Effect of calcium and calmodulin antagonists on ethylene biosynthesis in tomato fruits. J Sci Food Agric, 76, 209-214 (1998)

Noonari S, Irfana NM, Raiz AB, Muhammad IK, Ali S. Price flexibility and seasonal variations of major vegetables in Sindh Pakistan. J Food Proceess Technol, 6, 12 (2015)

Opiyo AM, Ying TJ. The effects of 1-methylcyclopropene treatment on the shelf life and quality of cherry tomato (Lycopersicon esculentum var. cerasiforme) fruit. Int $\mathrm{J}$ Food Sci Technol, 40, 665-673 (2005)

Park MH, Sangwanangkul P, Choi JW. Reduced chilling injury and delayed fruit ripening in tomatoes with modified atmosphere and humidity packaging. Sci Hortic, 231, 66-72 (2018)

Pristijono P, Papoutsis K, Scarlett CJ, Bowyer MC, Vuong QV, Stathopoulos CE, Golding JB. Postharvest UV-C treatment combined with 1-methylcyclopropene (1-MCP), followed by storage in continuous low-level ethylene atmosphere, improves the quality of tomatoes. J Hortic Sci Biotechnol, 92, 521-529 (2017)

Re R, Pellegrini N, Proteggente A, Pannala A, Yang M, Rice-Evans C. Antioxidant activity applying an improved ABTS radical cation decolorization assay. Free Radical Biol Med, 26, 1231-1237 (1999)

Roberts KP, Sargent SA, Fox AJ. Effect of storage 
temperature on ripening and postharvest quality of grape and mini-pear tomatoes. Proc Fla State Hort Soc, 115, 80-84 (2002)

Sams CE, Conway WS, Abbott JA, Lewis RJ, Ben Shalom N. Firmness and decay of apples following postharvest pressure infiltration of calcium and heat treatment. J Am Soc Hortic Sci 118, 623-627 (1993)

Senevirathna PAWANK, Daundasekera WAM. Effect of postharvest calcium chloride vacuum infiltration on the shelf life and quality of tomato (cv. Thilina'). Ceyl J Sci, 39, 35-44 (2010)

Shahidi F, Naczk M. Food Phenolics: Sources, Chemistry, Effects and Applications. Technomic Publishing Co Inc, Lancaster, PA, USA, p 225-289 (1995)

Shiri MA, Ghasemnezhad M, Fatahi MJ, Moghaddam JF. Fruit growth and sensory evaluation of Hayward kiwifruit in response to preharvest calcium chloride application and orchard location. Agric Conspec Sci, 79, 183-189 (2014)

Smith CJS, Watson CF, Morris PC, Bird CR, Seymour GB, Gray JE, Arnold C, Tucker GA, Schuch W, Harding S, Grierson D. Inheritance and effect on ripening of antisense polygalacturonase genes in transgenic tomatoes. Plant Mol Biol, 14, 369-379 (1990)
Swain T, Hillis WE. The phenolic constituents of Prunus domestica. I. The quantitative analysis of phenolic constisuents. J Sci Food Agric, 10, 63-68 (1959)

Vicente AR, Manganaris GA, Sozzi GO, Crisosto $\mathrm{CH}$. Nutritional quality of fruits and vegetables. In: Postharvest Handling: A Systems Approach, Florkowski WJ, Shewfelt RL, Brueckner B, Prussia SE (Editors), Academic Press, Cambridge, MA, USA, p 57-106 (2009)

Wakabayashi K, Chun JP, Huber DJ. Extensive solubilization and depolymerization of cell wall polysaccharides during avocado (Persea americana) ripening involves concerted action of polygalacturonase and pectinmethylesterase. Physiol Plant, 108, 345-352 (2000)

Watkins CB. The use of 1-methylcyclopropene (1-MCP) on fruits and vegetables. Biotechnol Adv, 24, 389-409 (2006)

Wills $\mathrm{RBH}, \mathrm{Ku} \mathrm{VVV}$. Use of 1-MCP to extend the time to ripen of green tomatoes and postharvest life of ripe tomatoes. Postharvest Biol Technol, 26, 85-90 (2002)

Wills RHH, Lee TH, Graham WB, Hall EG. Postharvest: An Introduction to the Physiology and Handling of Fruit and Vegetables. Avi publishing Co, Westport, CT, USA, p 78-89 (1981) 